\title{
Pengaruh Harga, Kualitas, Keragaman Produk dan Lokasi Pasar Terhadap Preferensi Konsumen Dalam Membeli Produk Pertanian di Pasar Tradisional Berastagi
}

\author{
Oleh : \\ Rasmulia Sembiring* \\ Universitas Methodist Indonesia Medan \\ Email: rasmuliasembiring11@gmail.com
}

\begin{abstract}
Abstrak
Penelitian ini bertujuan untuk mengetahui pengaruh harga, kualitas dan keragaman produk, serta lokasi pasar terhadap preferensi konsumen dalam membeli produk pertanian di Pasar Tradisional Brastagi. Pengambilan sampel diambil dengan menggunakan metode jenis purposive sampling, dimana sampel merupakan pelanggan pasar tradisional yang telah berkunjung lebih dari 2 kali dengan jumlah sampel sebanyak 60 responden. Adapun variabel yang akan diteliti adalah harga, kualitas produk, keragaman produk dan lokasi pasar. Metode analisis data yang digunakan dalam penelitian ini adalah regresi linear berganda. Hasil penelitian menunjukkan bahwa semua variabel harga, kualitas, keseragaman produk dan lokasi pasar berpengaruh secara signifikan terhadap preferensi konsumen.
\end{abstract}

Kata kunci : produk; kualitas; keragaman; pasar; preferensi; konsumen

\begin{abstract}
The aims of this research was to determine the effect of price, quality, product variety and market location to consumer preferences in buying agriculture product in Brastagi traditional market. Purposive sampling used in this research taken the sampling where the sample was a traditional market costumers whom visits more than two times with the numbers of sample 60 respondent. data analyzed used multiple regression linier. Result show that all the variables price, quality, variety of product and market location affected significantly to consumers references.
\end{abstract}

Keyword: product; quality; variety, market; preference, consumer

\section{PENDAHULUAN}

Dalam kehidupan sehari-hari, manusia membutuhkan adanya kebutuhan pangan yang harus dipenuhi. Kebutuhan sehari-hari tersebut dapat dipenuhi dengan membeli bahan pangan tersebut di pasar tradisional. Berdasarkan informasi dari para pedagang pasar di pasar tradisonal, ternyata kini jumlah konsumen yang berkunjung dan membeli di pasar tradisional semakin hari cenderung semakin berkurang, akibat sembakin banyaknya tumbuh pasar tradisional. Omzet penjualan pun cenderung menurun. Bila dibandingkan dengan keadaan 5 tahun yang lalu, dimana waktu itu berjualan dimulai dari jam 8 pagi sampai dengan jam 4 siang, barang dagangan buah-buahan yang terjual sudah habis. Tetapi kini, dengan jumlah kuantitas barang yang ditawarkan relatif sama, namun memerlukan waktu yang lebih lama yaitu sejak jam 8 pagi sampai jam 6 sore, bahkan seringkali barang dagangan (hasil-hasil pertanian) yang ditawarkan tidak laku terjual. Hal tersebut tentu saja sangat merugikan para pedagang.

Bergesernya preferensi pola pembelian konsumsi masyarakat dalam memenuhi kebutuhannya, disebabkan 
antara lain mulai pudarnya beberapa pamor pasar tradisional. Masyarakat saat ini tidak hanya sekadar berbelanja untuk memenuhi kebutuhannya saja tetapi juga untuk bersosialisasi dan rekreasi. Preferensi masyarakat (konsumen) dalam berbelanja buahan-buahan dan sayursayuran di beberapa pasar tradisional di Kabupaten Karo cenderung menurun juga disebabkan karena masyarakat lebih memilih berbelanja di tempat lain yang menawarkan berbagai macam produk dengan harga bersaing dan kenyamanan dalam berbelanja. Disamping itu harga dapat mempengaruhi preferensi masyarakat dalam berbelanja.

Pasar tradisional merupakan tulang punggung perekonomian yang tak bisa dibiarkan tergerus oleh pasar moderen yang semakin menjamur, karena pasar ini melibatkan jutaan pedagang yang relatif berskala kecil. Dapat dibayangkan, jika separuh dari jumlah pedagang ini gulung tikar karena dagangannya selalu rugi dan tidak dapat bertahan di tengah derasnya persaingan usaha yang semakin ketat dibandingkan dengan pasar modern, hasilnya adalah jumlah pengangguran Indonesia yang semakin meningkat. Selain itu, pasar tradisional juga dianggap sebagai pusat jalur pemasaran hasil produksi kalangan pengusaha kecil maupun sumber pasokan bahan baku yang dibutuhkan industri yang dinilai sangat strategis bagi pengembangan ekonomi masyarakat.

Jika pengelolaan terhadap kelangsungan hidup pasar tradisional tidak mendapatkan perhatian yang serius dari pemerintah, maka akan menimbulkan dampak sosial yang cukup signifikan, karena, di pasar tradisional terdapat ratusan pedagang yang bekerja secara infomal. Bila para pedagang mengalami kerugian secara permanen, mereka akan bangkrut, dan akibatnya akan kehilangan mata pencaharian. Hilangnya mata pencaharian akan mengakibatkan beban bagi dirinya sendiri, masyarakat dan pemerintah. Kerawanan sosial, ketidakpuasan, dan kualitas hidup yang semakin menurun, merupakan dampak yang harus diperhatikan.

$$
\text { Dari hasil observasi dapat }
$$

diketahui dari bebrapa pasar tradisional buah dan sayuran yang ada di Kabupaten Karo, pasar tradisional Brastagi memiliki pengunjung konsumen yang lebih banyak dibandingkan dengan pasar tradisional yang ada di tiga panah dan bahkan dari pasar tradisional yang ada di Kota Kabanjahe. Hal ini disebabkan oleh berbagai faktor yaitu harga, kualitas produk, lokasi dan keragaman produk. Faktor-faktor ini diduga mempengaruhi jumlah pembeli yang belanja di pasar tradisional Brastagi. Oleh karena itu penelitian ini bertujuan untuk mengetahui pengaruh harga, kualitas, keragaman produk dan lokasi pasar terhadap preferensi konsumen dalam membeli produk pertanian di Pasar Tradisional Brastagi.

\section{METODE PENELITIAN}

Populasi adalah wilayah generalisasi yang terdiri dari objek atau subjek yang mempunyai kuantitas dan karakteristik tertentu yang ditetapkan oleh peneliti untuk dipelajari dan kemudian ditarik kesimpulan (Sugiyono, 2013:80). Populasi dalam penelitian ini adalah seluruh pelanggan pasar tradisional Brastagi.

Sampel adalah bagian dari jumlah dan karakteristik yang dimiliki oleh populasi. Metode pemilihan sampel dalam penelitian ini adalah dengan menggunakan Non Probability Sampling, yaitu teknik pengambilan sampel yang tidak memberi peluang atau kesempatan yang sama bagi setiap unsur atau anggota populasi untuk dipilih menjadi sampel (Sugiyono, 2013:84). Pengambilan sampel diambil dengan menggunakan metode jenis purposive sampling, karena didalam menentukan sampel ada pertimbangan 
kriteria tertentu, yaitu sampel adalah pelanggan pasar tradisional yang telah berkunjung lebih dari 2 kali. Pengambilan sampel dilakukan di pasar tradisional Brastagi dengan jumlah sampel sebanyak 60 responden. Menurut Supranto (2011:239), jumlah sampel sebanyak 30 responden merupakan persyaratan minimal dalam suatu penelitian, dimana semakin besar sampel akan memberikan hasil yang lebih akurat.

Adapun variabel yang akan diteliti adalah harga $\left(\mathrm{X}_{1}\right)$, kualitas produk $\left(\mathrm{X}_{2}\right)$, keragaman produk $\left(\mathrm{X}_{3}\right)$ dan lokasi pasar $\left(\mathrm{X}_{4}\right)$ sebagai variabel independen, sedangkan preferensi konsumen (Y) sebagai variabel dependent. Metode analisis data yang digunakan dalam penelitian ini adalah regresi linear berganda.

\section{HASIL DAN PEMBAHASAN}

Tanggapan Responden terhadap Variabel yang Diamati

a. Variabel Harga Produk $\left(\mathrm{X}_{1}\right)$

Tanggapan responden dari kuesioner yang telah disebarkan, sebagaimana seperti pada tabel sebagai berikut :

Tabel 1. Tanggapan Responden tentang Indikator Harga Produk

\begin{tabular}{|c|c|c|c|c|c|c|c|c|c|c|c|c|c|}
\hline \multirow{3}{*}{ No } & \multirow{3}{*}{ Pernyataan } & \multicolumn{10}{|c|}{ Jawaban } & \multirow{2}{*}{\multicolumn{2}{|c|}{ Total }} \\
\hline & & \multicolumn{2}{|c|}{ SS } & \multicolumn{2}{|c|}{$\mathbf{S}$} & \multicolumn{2}{|c|}{$\mathbf{N}$} & \multicolumn{2}{|c|}{ TS } & \multicolumn{2}{|c|}{ STS } & & \\
\hline & & $\mathbf{N}$ & $\%$ & $\mathbf{n}$ & $\%$ & $\mathbf{n}$ & $\%$ & $\mathbf{n}$ & $\%$ & $\mathbf{n}$ & $\%$ & $\mathbf{n}$ & $\%$ \\
\hline 1. & Harga lebih terjangkau & 13 & 21,7 & 10 & 16,7 & 14 & 23,3 & 16 & 26,7 & 7 & 11,7 & 60 & 100 \\
\hline 2. & $\begin{array}{l}\text { Kesesuaian harga dengan } \\
\text { kualitas produk }\end{array}$ & 9 & 15,0 & 10 & 16,7 & 8 & 13,3 & 9 & 15,0 & 24 & 40,0 & 60 & 100 \\
\hline 3. & Harga dapat ditawar & 7 & 11,7 & 14 & 23,3 & 21 & 35,0 & 5 & 8,3 & 13 & 21,7 & 60 & 100 \\
\hline 4. & $\begin{array}{l}\text { Harga mempengaruhi daya beli } \\
\text { konsumen }\end{array}$ & 11 & 18,3 & 12 & 20,0 & 17 & 28,3 & 11 & 18,3 & 9 & 15,0 & 60 & 100 \\
\hline
\end{tabular}

Sumber : Data Diolah (2017)

Tanggapan responden terhadap harga secara rinci menunjukkan bahwa responden yang menyatakan "harga lebih terjangkau dibanding pasar tradisional lainnya", responden yang menyatakan Sangat Setuju (SS) sebanyak 13 orang (21,7\%), menyatakan Setuju (S) 10 orang $(16,7 \%)$, menyatakan Netral (N) 14 orang $(23,3 \%)$ dan menyatakan Tidak Setuju (TS) sebanyak 16 orang (26,7\%) serta menyatakan Sangat Tidak Setuju (STS) sebanyak 7 orang $(11,7 \%)$. Responden yang menyatakan "kesesuaian harga dengan kualitas produk", responden yang menyatakan Sangat Setuju (SS) sebanyak 9 orang (15\%), menyatakan Setuju (S) 10 orang $(16,7 \%)$, menyatakan Netral $(\mathrm{N}) 8$ orang $(13,3 \%)$ dan menyatakan Tidak Setuju (TS) sebanyak 9 orang (15\%) serta menyatakan Sangat Tidak Setuju (STS) sebanyak 24 orang (40\%). Responden yang menyatakan "harga dapat ditawar", responden yang menyatakan Sangat Setuju (SS) sebanyak 7 orang $(11,7 \%)$, menyatakan Setuju (S) 14 orang (23,3\%), menyatakan Netral (N) 21 orang (35\%) dan menyatakan Tidak Setuju (TS) sebanyak 5 orang $(8,3 \%)$ serta menyatakan Sangat Tidak Setuju (STS) sebanyak 13 orang $(21,7 \%)$. Responden yang menyatakan "harga mempengaruhi daya beli konsumen", responden yang menyatakan Sangat Setuju (SS) sebanyak 11 orang (18,3\%), menyatakan Setuju (S) 12 orang $(20 \%)$, menyatakan Netral (N) 17 orang $(28,3 \%)$ dan menyatakan Tidak Setuju (TS) sebanyak 11 orang (18,3\%) serta menyatakan Sangat Tidak Setuju (STS) sebanyak 9 orang $(15,0 \%)$. 
b. Variabel Kualitas Produk $\left(\mathrm{X}_{2}\right)$

Tanggapan responden dari kuesioner yang telah disebarkan, sebagaimana seperti pada tabel sebagai berikut :

Tabel 2. Tanggapan Responden tentang Indikator Kualitas Produk

\begin{tabular}{|c|c|c|c|c|c|c|c|c|c|c|c|c|c|}
\hline \multirow{3}{*}{ No } & \multirow{3}{*}{ Pernyataan } & \multicolumn{10}{|c|}{ Jawaban } & \multirow{2}{*}{\multicolumn{2}{|c|}{ Total }} \\
\hline & & \multicolumn{2}{|c|}{ SS } & \multicolumn{2}{|c|}{$\mathbf{S}$} & \multicolumn{2}{|c|}{$\mathbf{N}$} & \multicolumn{2}{|c|}{ TS } & \multicolumn{2}{|c|}{ STS } & & \\
\hline & & $\mathbf{N}$ & $\%$ & $\mathbf{n}$ & $\%$ & $\mathbf{n}$ & $\%$ & $\mathbf{n}$ & $\%$ & $\mathbf{n}$ & $\%$ & $\mathbf{n}$ & $\%$ \\
\hline 1. & $\begin{array}{lll}\begin{array}{l}\text { Kesesuaian } \\
\text { mutu }\end{array} & \text { dengan standar } \\
\end{array}$ & 18 & 30,0 & 20 & 33,3 & 11 & 18,3 & 8 & 13,3 & 3 & 5,0 & 60 & 100 \\
\hline 2. & Produk memiliki keistimewaan & 5 & 8,3 & 15 & 25,0 & 22 & 36,7 & 9 & 15,0 & 9 & 15,0 & 60 & 100 \\
\hline 3. & Produk memiliki estetika & 6 & 10,0 & 15 & 25,0 & 19 & 31,7 & 16 & 26,7 & 4 & 6,7 & 60 & 100 \\
\hline 4. & Kemampuan pelayanan & 9 & 15,0 & 13 & 21,7 & 20 & 33,3 & 12 & 20,0 & 6 & 10,0 & 60 & 100 \\
\hline
\end{tabular}

Sumber : Data Diolah (2017)

Tanggapan responden terhadap harga secara rinci menunjukkan bahwa responden yang menyatakan "kesesuain dengan standar mutu", responden yang menyatakan Sangat Setuju (SS) sebanyak 18 orang (30\%), menyatakan Setuju (S) 20 orang $(33,3 \%)$, menyatakan Netral (N) 11 orang $(18,3 \%)$ dan menyatakan Tidak Setuju (TS) sebanyak 9 orang (15\%) serta menyatakan Sangat Tidak Setuju (STS) sebanyak 9 orang (15\%). Responden yang menyatakan "produk memiliki keistimewaan", responden yang menyatakan Sangat Setuju (SS) sebanyak 5 orang (8,3\%), menyatakan Setuju (S) 15 orang (25\%), menyatakan Netral (N) 22 orang $(36,7 \%)$ dan menyatakan Tidak Setuju (TS) sebanyak 9 orang (15\%) serta menyatakan Sangat Tidak Setuju (STS) sebanyak 9 orang (15\%). Responden yang menyatakan "produk memiliki estetika", responden yang menyatakan Sangat Setuju
(SS) sebanyak 6 orang (10 \%), menyatakan Setuju (S) 15 orang (25\%), menyatakan Netral (N) 19 orang (31,7\%) dan menyatakan Tidak Setuju (TS) sebanyak 16 orang $(26,7 \%)$ serta menyatakan Sangat Tidak Setuju (STS) sebanyak 4 orang $(6,7 \%)$. Responden yang menyatakan "kemampuan pelayanan", responden yang menyatakan Sangat Setuju (SS) sebanyak 9 orang (15\%), menyatakan Setuju (S) 13 orang $(21,7 \%)$, menyatakan Netral (N) 20 orang (33,3\%) dan menyatakan Tidak Setuju (TS) sebanyak 12 orang $(33,3 \%)$ serta menyatakan Sangat Tidak Setuju (STS) sebanyak 6 orang $(10 \%)$.

c. Variabel Keragaman Produk $\left(\mathrm{X}_{3}\right)$

Tanggapan responden dari kuesioner yang telah disebarkan, sebagaimana seperti pada tabel sebagai berikut :

Tabel 3. Tanggapan Responden tentang Indikator Keragaman Produk

\begin{tabular}{|c|c|c|c|c|c|c|c|c|c|c|c|c|c|}
\hline \multirow{3}{*}{ No } & \multirow{3}{*}{ Pernyataan } & \multicolumn{10}{|c|}{ Jawaban } & \multirow{2}{*}{\multicolumn{2}{|c|}{ Total }} \\
\hline & & \multicolumn{2}{|c|}{ SS } & \multicolumn{2}{|c|}{$\mathbf{S}$} & \multicolumn{2}{|c|}{$\mathbf{N}$} & \multicolumn{2}{|c|}{ TS } & \multicolumn{2}{|c|}{ STS } & & \\
\hline & & $\mathbf{N}$ & $\%$ & $\mathbf{n}$ & $\%$ & $\mathbf{n}$ & $\%$ & $\mathbf{n}$ & $\%$ & $\mathbf{n}$ & $\%$ & $\mathbf{n}$ & $\%$ \\
\hline 1. & Jenis produk beragam & 13 & 21,7 & 21 & 35,0 & 17 & 28,3 & 8 & 13,3 & 1 & 1,7 & 60 & 100 \\
\hline 2. & Ukuran produk yang beragam & 11 & 18,3 & 20 & 33,3 & 13 & 21,7 & 13 & 21,7 & 3 & 5,0 & 60 & 100 \\
\hline 3. & Kualitas produk yang beragam & 10 & 16,7 & 14 & 23,3 & 13 & 21,7 & 16 & 26,7 & 7 & 11,7 & 60 & 100 \\
\hline
\end{tabular}

Sumber : Data Diolah (2017) 
Tanggapan responden terhadap harga secara rinci menunjukkan bahwa responden yang menyatakan "jenis produk beragam", responden yang menyatakan Sangat Setuju (SS) sebanyak 13 orang (21,7\%), menyatakan Setuju (S) 21 orang (35\%), menyatakan Netral (N) 17 orang $(28,3 \%)$ dan menyatakan Tidak Setuju (TS) sebanyak 8 orang $(13,3 \%)$ serta menyatakan Sangat Tidak Setuju (STS) sebanyak 1 orang (1,7\%). Responden yang menyatakan "ukuran produk yang beragam", responden yang menyatakan Sangat Setuju (SS) sebanyak 11 orang (18,3\%), menyatakan Setuju (S) 20 orang (33,3\%), menyatakan Netral (N) 13 orang $(21,7 \%)$ dan menyatakan Tidak Setuju (TS) sebanyak 13 orang (21,7 \%) serta menyatakan Sangat Tidak Setuju (STS) sebanyak 3 orang (5\%). Responden yang menyatakan "kualitas produk yang beragam”, responden yang menyatakan Sangat Setuju (SS) sebanyak 10 orang (16,7 \%), menyatakan Setuju (S) 14 orang $(23,3 \%)$, menyatakan Netral (N) 13 orang (21,7\%) dan menyatakan Tidak Setuju (TS) sebanyak 16 orang (26,7\%) serta menyatakan Sangat Tidak Setuju (STS) sebanyak 7 orang $(11,7 \%)$.

\section{d. Variabel Lokasi Pasar $\left(\mathrm{X}_{4}\right)$}

Tanggapan responden dari kuesioner yang telah disebarkan, sebagaimana seperti pada tabel sebagai berikut :

Tabel 4. Tanggapan Responden tentang Indikator Lokasi Pasar

\begin{tabular}{|c|c|c|c|c|c|c|c|c|c|c|c|c|c|}
\hline \multirow{3}{*}{ No } & \multirow{3}{*}{ Pernyataan } & \multicolumn{10}{|c|}{ Jawaban } & \multirow{2}{*}{\multicolumn{2}{|c|}{ Total }} \\
\hline & & \multicolumn{2}{|c|}{ SS } & \multicolumn{2}{|c|}{ 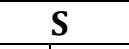 } & \multicolumn{2}{|c|}{$\mathbf{N}$} & \multicolumn{2}{|c|}{ TS } & \multicolumn{2}{|c|}{ STS } & & \\
\hline & & $\mathbf{N}$ & $\%$ & $\mathbf{n}$ & $\%$ & $\mathbf{N}$ & $\%$ & $\mathbf{n}$ & $\%$ & $\mathbf{n}$ & $\%$ & $\mathbf{n}$ & $\%$ \\
\hline 1. & Lokasi pasar strategis & 6 & 10,0 & 19 & 31,7 & 18 & 30,0 & 10 & 16,7 & 7 & 11,7 & 60 & 100 \\
\hline 2. & Lokasi pasar dilalui kendaraan umum & 5 & 8,3 & 9 & 15,0 & 17 & 28,3 & 19 & 31,7 & 10 & 16,7 & 60 & 100 \\
\hline 3. & $\begin{array}{l}\text { Lokasi pasar dapat dija } \\
\text { mudah }\end{array}$ & 11 & 18,3 & 7 & 11,7 & 20 & 33,3 & 17 & 28,3 & 5 & 8, & 60 & 100 \\
\hline
\end{tabular}

Sumber : Data Diolah (2017)

Tanggapan responden terhadap harga secara rinci menunjukkan bahwa responden yang menyatakan "lokasi pasar strategis", responden yang menyatakan Sangat Setuju (SS) sebanyak 6 orang (10\%), menyatakan Setuju (S) 19 orang $(31,7 \%)$, menyatakan Netral (N) 18 orang (30\%) dan menyatakan Tidak Setuju (TS) sebanyak 10 orang $(16,7 \%)$ serta menyatakan Sangat Tidak Setuju (STS) sebanyak 7 orang $(11,7 \%)$. Responden yang menyatakan "lokasi pasar dilalaui kendaraan umum", responden yang menyatakan Sangat Setuju (SS) sebanyak 5 orang (8,3\%), menyatakan Setuju (S) 9 orang (15\%), menyatakan Netral (N) 17 orang $(28,3 \%)$ dan menyatakan Tidak Setuju (TS) sebanyak 19 orang (31,7\%) serta menyatakan Sangat Tidak Setuju (STS) sebanyak 10 orang $(16,7 \%)$. Responden yang menyatakan "lokasi pasar dapat dijangkau dengan mudah", responden yang menyatakan Sangat Setuju (SS) sebanyak 11 orang (18,3\%), menyatakan Setuju (S) 7 orang $(11,7 \%)$, menyatakan Netral (N) 20 orang $(33,3 \%)$ dan menyatakan Tidak Setuju (TS) sebanyak 17 orang $(28,3 \%)$ serta menyatakan Sangat Tidak Setuju (STS) sebanyak 5 orang $(8,3 \%)$. 
e. Variabel Preferensi (Y)

Tanggapan responden dari

sebagaimana seperti pada tabel sebagai kuesioner yang telah disebarkan, berikut :

Tabel 5. Tanggapan Responden tentang Indikator Preferensi

\begin{tabular}{|c|c|c|c|c|c|c|c|c|c|c|c|c|c|}
\hline \multirow{3}{*}{ No } & \multirow{3}{*}{ Pernyataan } & \multicolumn{10}{|c|}{ Jawaban } & \multirow{2}{*}{\multicolumn{2}{|c|}{ Total }} \\
\hline & & \multicolumn{2}{|c|}{ SS } & \multicolumn{2}{|c|}{$\mathbf{S}$} & \multicolumn{2}{|c|}{$\mathbf{N}$} & \multicolumn{2}{|c|}{ TS } & \multicolumn{2}{|c|}{ STS } & & \\
\hline & & $\mathbf{N}$ & $\%$ & $\mathbf{n}$ & $\%$ & $\mathbf{n}$ & $\%$ & $\mathbf{N}$ & $\%$ & $\mathbf{n}$ & $\%$ & $\mathbf{n}$ & $\%$ \\
\hline 1. & $\begin{array}{l}\text { Tingkat kesukaan berbelanja di } \\
\text { pasar tradisional Brastagi }\end{array}$ & 9 & 15,0 & 19 & 31,7 & 25 & 41,7 & 5 & 8,3 & 2 & 3,3 & 60 & 100 \\
\hline 2. & $\begin{array}{l}\text { Frekuensi berkunjung ke pasar } \\
\text { tradisional Brastagi }\end{array}$ & 8 & 13,3 & 17 & 28,3 & 19 & 31,7 & 13 & 21,7 & 3 & 5,0 & 60 & 100 \\
\hline 3. & Produk yang dijual bersih & 14 & 23,3 & 17 & 28,3 & 16 & 26,7 & 10 & 16,7 & 3 & 5,0 & 60 & 100 \\
\hline 4. & Pasar tradisional Brastagi bersih & 10 & 16,7 & 21 & 35,0 & 16 & 26,7 & 12 & 20,0 & 1 & 1,7 & 60 & 100 \\
\hline
\end{tabular}

Sumber : Data Diolah (2017)

Tanggapan responden terhadap harga secara rinci menunjukkan bahwa responden yang menyatakan "tingkat kesukaan berbelanja di pasar tradisional Brastagi", responden yang menyatakan Sangat Setuju (SS) sebanyak 9 orang (15\%), menyatakan Setuju (S) 19 orang $(31,7 \%)$, menyatakan Netral (N) 25 orang $(41,7 \%)$ dan menyatakan Tidak Setuju (TS) sebanyak 5 orang $(8,3 \%)$ serta menyatakan Sangat Tidak Setuju (STS) sebanyak 2 orang (3,3\%). Responden yang menyatakan "Frekuensi berkunjung ke pasar tradisional Brastagi", responden yang menyatakan Sangat Setuju (SS) sebanyak 8 orang $(13,3 \%)$, menyatakan Setuju (S) 17 orang (28,3\%), menyatakan Netral (N) 19 orang (31,7\%) dan menyatakan Tidak Setuju (TS) sebanyak 13 orang $(21,7 \%)$ serta menyatakan Sangat Tidak Setuju (STS) sebanyak 3 orang (5\%). Responden yang menyatakan "produk yang dijual bersih", responden yang menyatakan Sangat Setuju (SS) sebanyak 14 orang $(23,3 \%)$, menyatakan Setuju (S) 17 orang (28,3\%), menyatakan Netral (N) 16 orang $(26,7 \%)$ dan menyatakan Tidak Setuju (TS) sebanyak 10 orang $(16,7 \%)$ serta menyatakan Sangat Tidak Setuju (STS) sebanyak 3 orang (5\%). Responden yang menyatakan "pasar tradisional Brastagi bersih", responden yang menyatakan Sangat Setuju (SS) sebanyak 10 orang $(16,7 \%)$, menyatakan Setuju (S) 21 orang (35\%), menyatakan Netral (N) 16 orang $(26,7 \%)$ dan menyatakan Tidak Setuju (TS) sebanyak 12 orang $(20 \%)$ serta menyatakan Sangat Tidak Setuju (STS) sebanyak 1 orang $(1,7 \%)$.

Pengujian regresi linear berganda menjelaskan pengaruh harga, kualitas, kergaman produk serta lokasi pasar terhadap preferensi pelanggan. Hasil analisis regresi dengan perhitungan yang menggunakan software SPSS selengkapnya dapat dilihat pada Tabel 6 . 
Tabel 6. Hasil Regresi Linier Berganda

Coefficients $^{a}$

\begin{tabular}{|c|c|c|c|c|c|c|}
\hline \multirow{2}{*}{\multicolumn{2}{|c|}{ Model }} & \multicolumn{2}{|c|}{ Unstandardized Coefficients } & \multirow{2}{*}{$\begin{array}{c}\begin{array}{c}\text { Standardized } \\
\text { Coefficients }\end{array} \\
\text { Beta } \\
\end{array}$} & \multirow[b]{2}{*}{$\mathrm{t}$} & \multirow[b]{2}{*}{ Sig. } \\
\hline & & $\mathrm{B}$ & Std. Error & & & \\
\hline \multirow[t]{5}{*}{1} & (Constant) & 1.539 & 1.625 & & .947 & .348 \\
\hline & Harga & .268 & .072 & .361 & 3.700 & .000 \\
\hline & Kualitas & .237 & .104 & .245 & 2.272 & .027 \\
\hline & Keseragaman & .355 & .135 & .287 & 2.618 & .011 \\
\hline & Lokasi_Pasar & .267 & .121 & .221 & 2.214 & .031 \\
\hline
\end{tabular}

a. Dependent Variable: Preferensi

Berdasarkan hasil tersebut maka persamaan regresi linier berganda yang mempunyai formulasi : $\mathrm{Y}=\mathrm{b}_{0}+\mathrm{b}_{1} \mathrm{X}_{1}+\mathrm{b}_{2} \mathrm{X}_{2}$ $+\mathrm{b}_{3} \mathrm{X}_{3}+\mathrm{b}_{4} \mathrm{X}_{4}+\varepsilon$, sehingga diperoleh persamaan : $\mathrm{Y}=1,539+0,268 \mathrm{X}_{1}+0,237$ $X_{2}+0,355 X_{3}+0,267 X_{4}$ dengan estimasi simpangan baku peramalan sebesar 2,219.

Deskripsi dari persamaan regresi linear berganda di atas adalah sebagai berikut :

\section{$\mathrm{b}_{0}: 1,539$}

Bilangan konstanta $\left(b_{0}\right)$ sebesar 1,539 menunjukkan besarnya preferensi konsumen apabila harga, kualitas, keseragaman produk dan lokasi pasar sama dengan 0 .

$b_{1}: 0,268$

Koefisien regresi pertama $\left(b_{1}\right)$ sebesar 0,268 menunjukkan besarnya peranan harga terhadap preferensi konsumen dengan asumsi kualitas, keseragaman produk dan lokasi pasar konstan. Artinya apabila faktor harga produk meningkat 1 satuan nilai, maka diprediksi preferensi konsumen meningkat sebesar 0,268 satuan nilai dengan asumsi kualitas, keseragaman produk dan lokasi pasar konstan.

$b_{2}: 0,237$

Koefisien regresi kedua $\left(b_{2}\right)$ sebesar 0,237 menunjukkan besarnya peranan kualitas produk terhadap preferensi konsumen dengan asumsi harga, keseragaman produk dan lokasi pasar konstan. Artinya apabila faktor kualitas produk meningkat 1 satuan nilai, maka diprediksi preferensi konsumen meningkat sebesar 0,237 satuan nilai dengan asumsi harga produk, keseragaman produk dan lokasi pasar konstan.

$b_{3}: 0,355$

Koefisien regresi ketiga $\left(b_{3}\right)$ sebesar 0,355 menunjukkan besarnya peranan keseragaman produk terhadap preferensi konsumen dengan asumsi harga produk, kualitas produk dan lokasi pasar konstan. Artinya apabila faktor keseragaman produk meningkat 1 satuan nilai, maka diprediksi preferensi konsumen meningkat sebesar 0,355 satuan nilai dengan asumsi harga, kualitas produk dan lokasi pasar konstan.

$\mathrm{B}_{4}: 0,267$

Koefisien regresi keempat $\left(b_{4}\right)$ sebesar $\quad 0,267$ menunjukkan besarnya peranan lokasi pasar terhadap preferensi konsumen dengan harga produk, kualitas produk dan keseragaman produk konstan. Artinya apabila faktor lokasi pasar meningkat 1 satuan nilai, maka diprediksi preferensi konsumen meningkat sebesar 0,267 satuan nilai dengan asumsi harga produk, kualitas produk dan keseragaman produk. 
Untuk menguji signifikannya harga terhadap preferensi konsumen. Hasil uji F produk, kualitas produk, keseragaman dapat dilihat pada Tabel 7 . produk dan lokasi pasar secara simultan

Tabel 7. Uji F

\begin{tabular}{|c|c|c|c|c|c|c|}
\hline \multicolumn{7}{|c|}{ ANOVA $^{b}$} \\
\hline \multicolumn{2}{|c|}{ Model } & $\begin{array}{l}\text { Sum of } \\
\text { Squares }\end{array}$ & df & Mean Square & $\mathrm{F}$ & Sig. \\
\hline \multirow[t]{3}{*}{1} & Regression & 292.897 & 4 & 73.224 & 14.859 & $.000^{a}$ \\
\hline & Residual & 271.037 & 55 & 4.928 & & \\
\hline & Total & 563.933 & 59 & & & \\
\hline
\end{tabular}

a. Predictors: (Constant), Lokasi_Pasar, Harga, Kualitas, Keseragaman

b. Dependent Variable: Preferensi

Berdasarkan hasil pengolahan data dengan SPSS, maka diketahui $\mathrm{F}_{\text {hitung }}$ sebesar 14,859 > $F_{\text {tabel }} 2,54$, sehingga $\mathrm{H}_{0}$ ditolak atau $\mathrm{H}_{1}$ diterima. Hal ini menunjukkan bahwa harga produk, kualitas produk, keseragaman produk dan lokasi pasar secara simultan mempunyai peranan signifikan meningkatkan preferensi konsumen karyawan.

Berdasarkan analisis koefisien determinasi parsial di atas diketahui bahwa peranan kepemimpinan lebih besar dibandingkan dengan komunikasi terhadap kinerja karyawan, oleh karena itu untuk menguji kebenarannya digunakan uji hipotesis parsial atau uji-t.

Berdasarkan hasil penelitian di atas maka dapat diketahui bahwa harga produk mempunyai pengaruh yang lebih dominan terhadap preferensi konsumen, diikuti dengan keseragaman produk, kualitas produk dan lokasi pasar.

Nilai yang dipergunakan dalam melihat koefisien determinasi dalam penelitian ini adalah pada kolom $R$ square. Hal tersebut dikarenakan variabel bebas lebih besar dari dua variabel. Nilai koefisien determinasi dapat dilihat pada Tabel 8.
Tabel 8. Nilai Koefisien Determinasi

\begin{tabular}{|c|c|c|c|c|}
\hline \multicolumn{5}{|c|}{ Model Summary } \\
\hline Model & $\mathrm{R}$ & R Square & $\begin{array}{l}\text { Adjusted R } \\
\text { Square }\end{array}$ & $\begin{array}{l}\text { Std. Error of } \\
\text { the Estimate }\end{array}$ \\
\hline 1 & $.721^{a}$ & .519 & .484 & 2.21990 \\
\hline
\end{tabular}

Besarnya nilai pengaruh tersebut ditunjukkan oleh nilai koefisien $\mathrm{R}$ square sebesar 0,519 atau 51,90 \% yaitu persentase harga produk $\left(\mathrm{X}_{1}\right)$, kualitas produk $\left(\mathrm{X}_{2}\right)$, keseragaman produk $\left(\mathrm{X}_{3}\right)$ dan lokasi pasar $\left(\mathrm{X}_{4}\right)$ terhadap preferensi konsumen $(\mathrm{Y})$ adalah sebesar 51,90\%. Sedangkan sisanya sebesar 48,10\% (100\% - 51,90\%) dipengaruhi oleh variabel lain di luar model penelitian ini.

\section{SIMPULAN}

Harga produk berpengaruh secara signifikan terhadap preferensi konsumen. Bila harga lebih murah dan terjangkau maka preferensi konsumen membeli produk di pasar tradisional Brastagi akan naik.Kualitas produk berpengaruh secara signifikan terhadap preferensi konsumen. Bila kualitas lebih baik maka preferensi konsumen membeli produk di pasar tradisional Brastagi akan naik. Keseragaman produk berpengaruh secara signifikan terhadap preferensi konsumen. Bila keseragaman produk semakin banyak maka preferensi konsumen membeli 
produk di pasar tradisional Brastagi akan naik. Lokasi pasar berpengaruh secara signifikan terhadap preferensi konsumen. Bila lokasi pasar semakin mudah dijangkau maka preferensi konsumen membeli produk di pasar tradisional Brastagi akan naik. Oleh karena itu harga harus lebih murah dan terjangkau serta tawar menawar harga dipertahankan dan keseragaman produk harus lebih lengkap sehingga dapat meningkatkan kunjungan konsumen belanja ke Pasar Brastagi.

\section{DAFTAR PUSTAKA}

Darmadi Durianto, 2004. Brand Equity Ten Strategi Memimpin Pasar. Jakarta :PT Gramedia Pustaka Utama.

Frank, Robert H. 2011. Microeconomics and Behavior. Eighth edition, Mc.Graw. Hill International Edition.

Kotler Philips dan Gary, Armstrong. 2008. Prinsip-prinsip pemasaran. Edisi 12. Jilid 1. Jakarta: Erlangga.

Kotler, Philip dan Keller, Kevin Lane. 2007. Marketing management. $12^{\text {th }}$ Edition. New Jersey: Pearson Education, Inc.

Kotler, Philip, 2009. The Consumer Behavior in Marketing Management. Published by Simon \& Schuster Pte.Ltd.

Mulyani, Yuliana. 2009. Analisis FaktorFaktor yang Mempengaruhi Loyalitas Pelanggan Pasar Swalayan dengan Kepuasan Sebagai Variabel Intervening (Studi Kasus Pada Pasar Swalayan Luwes di Purwodadi).
Dalam Jurnal Excellent Vol. 1 No. 2 Hal 97-122.

Nasution, M. N. 2010. Manajemen Mutu terpadu, Bogor: Ghalia Indonesia.

Pamungkas, Rizki. 2014 Faktor-Faktor yang Mempengaruhi Keberhasilan Usaha Pemegang Usaha Waralaba (Studi Kasus pada Waralaba Makanan dan Minuman Lokal di Kota Semarang). Skripsi. Universitas Diponegoro.

http://eprints.undip.ac.id/43661 L1/16 PAMUNGKAS.pdf.

Schiffman, Leon and Leslie Lazar Kanuk, 2009. Perilaku Konsumen. Edisi Ketujuh. Bandung: CV. Linda Karya.

Simamora, Bilson. 2012. Panduan Riset Perilaku Konsumen, Surabaya: Pustaka Utama.

Sugiyono, 2013. Metode Penelitian Kuantitatif, Kualitatifdan $R \& D$. Bandung: Alfabeta.

Supranto, J. 2011. Pengukuran Tingkat Kepuasan Pelanggan untuk Menaikkan Pangsa Pasar. Jakarta: Rineka Cipta.

Tan Erwin Rediono, 2011. Pengaruh Faktor Harga, Promosi dan Pelayanan terhadap Keputusan Konsumen untuk Belanja di Alfamart Surabaya. Jurnal Kewirausahaan Volume 5 Nomor 2 ISSN. 1978-4724.

Tjiptono, Fandy. 2005. Service Management Mewujudkan 
Layanan Prima. Yogyakarta : ANDI.

Wahyudi, Nur. 2014. Analisis FaktorFaktor Pemilihan Lokasi Usaha terhadap Kesuksesan Usaha Jasa Mikro di Kecamatan Sungai Kunjang. http://ejurnal.untagsmd.ac.id/in dex.php/EKM/article/viewFile/8 81/pdf128. 